\title{
The confusing state of the art in top management composition studies: A theoretical and empirical review
}

Citation for published version (APA):

van Olffen, W., \& Boone, C. A. J. J. (1997). The confusing state of the art in top management composition studies: A theoretical and empirical review. NIBOR, Netherlands Institute of Business Organization and Strategy Research. NIBOR Research Memorandum No. 11 https://doi.org/10.26481/umanib.1997011

Document status and date:

Published: 01/01/1997

DOI:

10.26481/umanib.1997011

Document Version:

Publisher's PDF, also known as Version of record

\section{Please check the document version of this publication:}

- A submitted manuscript is the version of the article upon submission and before peer-review. There can be important differences between the submitted version and the official published version of record. People interested in the research are advised to contact the author for the final version of the publication, or visit the DOI to the publisher's website.

- The final author version and the galley proof are versions of the publication after peer review.

- The final published version features the final layout of the paper including the volume, issue and page numbers.

Link to publication

\footnotetext{
General rights rights.

- You may freely distribute the URL identifying the publication in the public portal. please follow below link for the End User Agreement:

www.umlib.nl/taverne-license

Take down policy

If you believe that this document breaches copyright please contact us at:

repository@maastrichtuniversity.nl

providing details and we will investigate your claim.
}

Copyright and moral rights for the publications made accessible in the public portal are retained by the authors and/or other copyright owners and it is a condition of accessing publications that users recognise and abide by the legal requirements associated with these

- Users may download and print one copy of any publication from the public portal for the purpose of private study or research.

- You may not further distribute the material or use it for any profit-making activity or commercial gain

If the publication is distributed under the terms of Article 25fa of the Dutch Copyright Act, indicated by the "Taverne" license above, 
The confusing state of the art in top management

composition studies: A theoretical and empirical review

W. van Olffen and C. Boone

$\mathrm{NIBOR} / \mathrm{RM} / 97 / 11$

http://www-edocs.unimaas.nl/

J.E.Lit. code: M21

$n i b \circ r$

Netherlands Institute of

Business Organization

and Strategy Research

University of Maastricht

Faculty of Economics and Business Administration

P.O. Box 616

6200 MD Maastricht

The Netherlands

Phone: ++31 43 - 3883794

Fax : ++3143-3258495 


\section{Introduction}

The purpose of this paper is to provide a theoretical and empirical review of TMT composition research. This research is theoretically inspired by the old tradition of group dynamics research (e.g. Lewin, 1948; 1951) and later insights into the effects managers have in shaping the course and fates of organisations (e.g. Child, 1972). Throughout this paper we will develop a conceptual model linking team composition, behaviour and results. The paper is structured as follows. First, in section 2, we introduce the theoretical background of present TMT composition studies and their theoretical antecedents in the decisionmaking insights of the Carnegie School, strategic choice theory and group dynamics. A model is presented that underlies socalled upper echelons research into the effect of TMT composition on organisational outcomes. We will describe the kinds of variables typically used in upper echelons studies to characterize a team: team averages and team variety. A major theoretical debate will then be introduced on the different effects of member variety in a team. Based on this discussion we will make a first refinement to the original upper echelons model. Next, in section 3, we give a summary of empirical research into team composition variables that have received most attention in TMT studies so far, such as averages and spreads in age, tenure and educational or functional background. Section 4 provides a critical discussion of the empirical findings in relation to the model and identifies some theoretical and empirical shortcomings in the research carried out so far. From this discussion a final analytical model is derived for studying TMT composition, strategic choices, processes and results.

\section{Theoretical background}

\subsection{Origins and development of the upper echelons model}

Although group dynamics research has a long history in social psychology, the systematic linking of characteristics of a group of top managers [the top management team (TMT)] to organisational results was only started in the first half of the 1980s. In their seminal paper, Hambrick and Mason (1984: 193) argued for "[a] new emphasis in macro-organisational research: an emphasis on the dominant coalition of the organisation, in particular its top managers". Their call was followed by a large number of TMT studies. However, the claim that studying the role of the dominant organisational coalition would be a worthwhile undertaking was by no means new.

Based upon the theorists of the Carnegie School (Cyert and March, 1963; March and Simon, 1958), it had long been acknowledged that decisions in organisations are taken by boundedly rational people. The bounds on people's rationality, according to the Carnegie theorists, are brought about by the limited ability of individuals to process all information relevant for taking decisions in complex environments. Therefore, in order to cope with complexity, managers process only part of the relevant stimuli and filter information according to their own cognitive base. This base is composed of assumptions about future events, knowledge of alternatives and the consequences of alternatives (March and Simon, 1958). A person's cognitive base is formed by individual life experiences, including formal training and work history. Therefore, it is argued that a manager's specific perception of and response to environmental stimuli will partly depend upon the experiences (s)he has had during her/his life - that is, on her/his personal demography. The Carnegie School thus largely demystified the manager as a rational actor in the traditional sense of an objective optimizer but instead linked the decision maker's individual constitution to the choices (s)he makes. The connection between managerial choices and outcomes was made in the early 70 s, when strategic choice theorists (Child, 1972; 1974) developed and successfully tested the idea that company performance is not completely externally determined by market influences. Rather, managerial choices and strategies can play an important role in explaining performance differences between organisations in comparable contexts. 
The important contribution of Hambrick and Mason (1984) was to point at the potency of - and to stimulate systematic empirical research into - demographic variables like age, gender, and functional, educational and socio-economic backgrounds of the executive team in directly explaining a variety of organisational outcomes. Specifically, they provided an agenda to research the effects of these top management characteristics on organisational attributes such as types of strategies, extent and type of diversification, innovativeness and ultimately growth and variability in profit. Moreover, they underlined the relevance of existing social-psychological research into group heterogeneity or diversity for the study of top management teams. In this way, they linked the research tradition of group dynamics with that of strategic choice in the context of a specific type of groups: top management teams. This viewing of organisational strategic choices and performance levels as determined by managerial background characteristics was coined the upper echelons perspective.

In Hambrick and Mason's model (1984), shown in figure 1 below, two classes of managerial characteristics are distinguished: one observable, including personal and group demographic variables, and one psychological, including the individual's cognitive base and values. Combined, they influence the strategic choices TMTs make.

\section{INSERT FIGURE 1 ABOUT HERE}

These choices range from acquisition and product innovation decisions to issues of administrative structure and hierarchical authority. In turn, these choices produce organisational performance in terms of profit (variability), growth and survival. Hambrick and Mason (1984) argue that the TMT's influence on performance might come in two ways: direct and indirect. Two hypothetical examples will illustrate these effects. As for the direct effect, longer tenured teams may have so much industry experience that their response time to an arising strategic problem is condensed compared to that of a shorter tenured team which needs prolonged time to process information and sort things out. Therefore, although their ultimate strategic choice may be the same, the quicker response of the experienced team may contribute more to organisational performance than the relatively inexperienced team's lagged reaction. Note that with these direct effects it is not the particular choice but aspects of team processing and functioning that influence performance. Indirect effects arise when different team characteristics lead to different strategic choices and, consequently, different outcomes. Teams composed largely of people with economic business training may react differently to increased foreign competition compared with a team of technocrats. The former may be inclined to counter by cutting prices, whereas the latter may prefer to react by changing product designs to deliver higher perceived value.

Another important aspect of Hambrick and Mason's model is that the objective external and internal situation is included as well. Three reasons can be given for this. First, the objective situation co-determines which people rise to the top. Internal political processes and external industry norms place restrictions on people's upward mobility in organisations (Pfeffer, 1983). For example, technical industries, such as chemicals, tend to be dominated by managers holding technical degrees. Second, the nature and structure of an industry have a direct impact on strategic choices regarding such issues as acquisition, capital intensity and integration (Porter, 1980). Third, external and internal situational factors may impose important restrictions upon the manoeuvring space of managers as to their strategic choices. Societal pressure groups, legislation, market evolution, powerful boards of directors and/or company councils may severely limit the degrees of freedom upper echelons have in deciding on critical matters. This manoeuvring space is generally referred to as managerial discretion (Hambrick and Finkelstein, 1987). It is an important interaction variable in the general model by determining whether the effects of TMT characteristics on organisational outcomes will materialize. So, to sum up, in the upper echelons model psychological and observable characteristics of the TMT determine performance directly via team processes and indirectly via the strategic choices they lead to. The objective situation, both internal and external, also bears a direct influence on the characteristics of the TMT and on the strategic choices made. The team aspects that are of particular interest in TMT studies are discussed in the next paragraph.

\subsection{TMT variables and the multiple effects of variety}


Upper echelons studies employ a number of variables measuring aspects of the TMT that can be classified under two headings. First, we can look at the average or level of specific attributes of the team members, an example being average tenure. We may then theorize on how teams with different average tenures may differ in their behaviour and performance. These team-level hypotheses then, are merely extrapolations of what is expected and/or known at the individual level. For instance, as longtenured employees tend to develop rigid behavioural patterns and frames of reference, the same is expected of teams with long average tenure (Wiersema and Bantel, 1992). Second, we can focus on the spread or distribution of specific team members' attributes - for example in case we are interested in how age differences in teams affect processes and results of team interactions. Teams, then, can be either homogeneous (low spread) or heterogeneous (high spread) with regard to such characteristics. When it comes to the spread or variety of attributes (age, tenure, education) hypothesis generation is much more complex than it was in case of the averages where extrapolation to the team level sufficed. This is so because in case of variety, groups encounter specific problems in dealing with their inequality per se, that is, independent of the specific attribute on which they differ. For this reason we will have a more in depth look at the effect homogeneity or heterogeneity of teams has on their functioning and performance. Two theoretical perspectives on this issue can be distinguished. The first will be labelled the process facilitation perspective, which underscores the importance of homogeneity; the second is the resource diversity perspective, advocating heterogeneity. Both perspectives are discernable and recurrent throughout all hypothesizing on variety effects in the upper echelons studies we will encounter in the empirical section. We will treat the effects subsequently below.

\section{The process facilitation view}

Homogeneity at the group level means that group members are alike with regard to important attitudes and values. This similarity may be caused by the members being of roughly the same cohorts (Pfeffer, 1983). This implies that members in homogeneous groups share important dates (Ryder, 1965) and, consequently, life experiences. They were, for example, raised in the same era, studied in comparable school systems, entered the labour market under similar circumstances and have comparable careers. Moreover, at any point in time they probably share similar life stage experiences such as marrying, raising children, losing parents, et cetera. In fact, empirical studies in social psychology have demonstrated that people who are alike in attitude and socio-economic status tend to be attracted more to each other and exchange a larger number of positive reinforcements (Byrne, Clore \& Worchel, 1966) than people who are different in these respects. When those relatively similar people form a group, they are therefore expected to show greater social integration and cohesion because they share important frames of reference, attitudes and values (McCain, O'Reilly and Pfeffer, 1983; Wagner, Pfeffer and O'Reilly, 1984). In effect, a positive association between homogeneity and cohesion was shown in several group studies including top management teams (Katz, 1982; O'Reilly, Caldwell and Barnett, 1989). Similar frames of reference among team members facilitate communication frequency and effectiveness (Wagner, Pfeffer and O'Reilly, 1984; Zenger and Lawrence, 1989), which is, in turn, thought to produce superior team social integration and, ultimately, organisational performance (Smith et al., 1994).

There is, however, a dark side to homogeneity. It was already noted that homogeneity generally enhances cohesion and social integration. Moreover, cohesive groups reveal greater conformity (Lott and Lott, 1961). This may imply that social acceptability is maintained at the cost of lower criticism towards other group members and their contributions and also a decreased ability to critically evaluate (strategic) alternatives and environmental developments. The group becomes less open to absorbing information (Whitney \& Smith, 1983) and discussing novel behavioural patterns. This set of group pathologies is well documented under the name of groupthink (Janis, 1972), involving a general decrease in mental efficiency by which the desire for consensus and group unity in cohesive groups overrides the realistic appraisal of alternative courses of action. In their fear of 'rocking the boat', victims of groupthink tend to conform to the communis opinio within the group even if privately they have serious doubts about its correctness. This may lead to escalating commitment to existing choices and strategies (Brockner, 1992), especially when these were successful in the past (Hambrick, Geletkanycz and Frederickson, 1993). 
The resource diversity view

If a group faces a complex decision environment, team performance may benefit from having a wide range of viewpoints that can be discussed and evaluated critically. In order to cope with the multi-faceted issues that arise in a complex environment, solutions must be ingenious. Team heterogeneity is likely to facilitate the 'production' of such a wide spectrum of perspectives. As people are the carriers of cognitive capacities and as there are limits to the cognitive complexity an individual can handle (Cyert and March, 1963), every team member can provide only part of the diversity needed to solve the problem. The cognitive resources must therefore be pooled to solve complex dilemmas: teams should be diverse to accomplish this. Empirical research indeed reveals that in solving complex and non-routine problems groups are more effective when composed of members with a variety of skills, knowledge, abilities and perspectives (Filley, House and Kerr, 1976; Shaw, 1976; Wanous and Youtz, 1986). Especially innovation seems to be enhanced by heterogeneity of team members (Bantel and Jackson, 1989; Katz, 1982; Murray, 1989). Diversity with regard to psychological types is also advocated (Belbin, 1981; Blaylock, 1983; Hurst, Rush and White, 1989).

Nonetheless, heterogeneity has important drawbacks in relation to group processes. As team members have diverging frames of reference, attitudes and values, communication is hampered (McCain, O'Reilly and Pfeffer, 1983; Zenger and Lawrence, 1989). This, in turn, enhances the chances of conflicts, turnover (Wagner, Pfeffer and O'Reilly, 1984) and power struggles to occur (Pfeffer, 1983), attracting attention away from the immediate tasks of the group. According to group dynamics theorists, there is a tradeoff between group-maintenance and task-oriented behaviour (Shaw, 1976). This means that the operational efficiency of the heterogeneous team in performing its tasks is threatened because much time and energy are required to overcome communication barriers and power games.

\section{A balance}

Relative homogeneity and heterogeneity endow the team with different strengths and weaknesses. On the positive side, homogeneity lowers communication barriers and eases member interactions, whereas heterogeneity provides creativity and innovativeness in problem solving. On the negative side, homogeneity can lead to apathy, non-responsiveness and a lack of critical spirit, while heterogeneity hinders effective communication and wastes resources (especially time) in power struggles. However, organisations and teams operate in different environments in which the pros and cons of team composition may have a diverging impact on organisational functioning and effectiveness. An important moderator is environmental turbulence. High turbulence in the organisation's environment requires the organisation to be creative in adapting to changing environmental demands. This would call for a heterogeneous team regarding functional speciality, educational background and/or personality. Conversely, a stable environment may require the task-orientedness of a homogeneous team. In addition, low turbulence decreases the necessity to be creative and innovative. So, under specific environmental contingencies different team compositions may be warranted to arrive at a balance between homo- and heterogeneity effects that facilitate team performance most. A review of three decades of literature concerning the effects of diversity in different environments (Maznevski, 1994) suggests, that member diversity will only realize its potential and improve performance if members can understand each other and combine and build on each others' ideas, that is: if integration is achieved among the diverse members. For instance, a study by Abrahamson (1992) revealed that the companies most successful in entering a new market were those headed by TMTs high on both diversity and integration.

\subsection{The model refined}

Now that we have assessed the importance of the above processes in determining outcomes in teams, we are ready to incorporate them more formally in our own stylized model. See figure 2 . 
INSERT 2 ABOUT HERE

The direct path of Hambrick and Mason has now been replaced by the influence of team composition on the processes within the team. In accordance with the two perspectives above, team composition can have an affective effect (social integration) and a cognitive effect (breadth of perspective and creativity). Both effects will influence performance. For instance, poor communication in heterogeneous groups may delay decision making so as to miss opportunities; groups dominated by seniors may take more conservative strategic choices than juniors-dominated teams. From the present model, it should already be evident that many variables interact in determining the ultimate impact of group composition on performance. In the next section we will present the evidence on this matter.

\section{Empirical TMT composition research}

In the present section we will summarize the empirical research on TMT composition within the upper echelons framework. Thus, although we rely on a broader tradition of group (diversity) research to form our expectations, we will confront these with existing empirical findings in TMT settings. This means that in this review we will not deal with aspects of organisational diversity that, to our knowledge, have not yet been studied at the level of TMTs, like for instance race or ethnic background, nationality, gender and personality (see also Milliken and Martins, 1996). Instead we will report on the effects of compositional variables like age, tenure and functional experience that have attracted most attention so far. These compositional variables all touch in some way or the other on the amount (average) and diversity (heterogeneity) of experience the TMT contains by way of its members. Experiences can be diverse in nature. They may be life experiences (as in chronological age), team experiences (as in TMT tenure), organisational experiences (as in organisational tenure), industry experiences (as in industry tenure), functional experiences (as in member's functional backgrounds) and educational experiences (as in professional/ educational background).

In the next two sections we will ask ourselves what effects may be expected of the average amounts (3.1) and variety (3.2) of experiences in TMTs and what the empirical evidence looks like. Section 3.3 summarizes the results.

\subsection{Average experiences}

Intuitively, high average experience in a team will improve its performance. This would be a simple human capital way of looking at it: the more experience people have in a certain area, the better they will be able to interpret their situation and the more effective they will be in dealing with the problems they confront. However, this way of reasoning tends to hold overly optimistic assumptions about people's memories and flexibility in interpreting and applying knowledge. In fact, experience tends to form frames of reference that may lead to habitual routines in interpreting and acting upon problems (Pfeffer, 1983; Finkelstein and Hambrick, 1990). If so, teams highly experienced in certain areas may have difficulty in handling the new and unexpected that occupy no place (yet) in the industrial, organisational or functional paradigm on which they act. In fact, they may not even notice it. Thus, high experience can both enhance and hinder performance partly depending on the flexibility needed.

Average age 
Team members' average age is likely to affect the functioning of teams for a number of reasons. First, when comparing teams of high versus low average age ${ }^{1}$ it is important to note that young teams were raised and educated in another epoch than old teams. Depending on the specific socio-economic situations that prevailed during their way to the top they will probably hold different values, outlooks and practices concerning their work. Thus, their behaviour and results are likely to reflect their age. Assessing the impact of these differing views on team results is however very difficult. To the present author's knowledge no empirical study has yet been undertaken to see what age-related viewpoint differences between teams affect strategies and performance. Second, ageing seems to have a detrimental effect on cognitive faculties like learning ability, reasoning and memory (Botwinick, 1977; Burke and Light, 1981). This may generally have a negative bearing on executives' functioning as they get older. Third, younger managers were empirically found to have more favourable attitudes towards risk taking (Vroom and Pahl, 1971). Moreover, managerial youth is thought to be associated with much risky experimenting due to relative lack of experience. Thus, higher risk taking among younger managers, is a combined result of their risk taking attitude and the way they necessarily go about in learning the rules of the game. Older teams then, are thought to be characterized by a certain conservatism which, according to Hambrick and Mason (1984) is due to physical and mental limitations (Child, 1974), greater psychological commitment to the status quo (Stevens, Beyer \& Trice, 1978) or financial and career security considerations (Carlsson \& Karlsson, 1970).

These theoretical and empirical results have prompted researchers to hypothesize mainly on two issues in relation to the average age of team members (Hambrick and Mason, 1984). First, youth was expected to lead to the pursuit of risky strategies involving innovation and diversification ${ }^{2}$. This hypothesis was already backed by evidence mentioned above on younger managers' riskier attitude. Second, as innovation and diversification strategies, when successful, will lead to expansion, companies experiencing above industry average rates of growth and profit variability are more likely to be led by teams that have relatively low average ages. Previous research does indeed suggest managerial youth to be associated with corporate growth (Child, 1974; Hart and Mellons, 1970), although the direction of causality in these models remains unclear.

Few recent empirical studies into the effects of average TMT member age exist. The research by Wiersema and Bantel (1992) (see Appendix) lends support to the hypothesis that older teams lead companies experiencing less strategic change. However, in Bantel and Jackson's (1989) study the hypothesized direct association between average TMT age and innovativeness did not materialize. Instead, a negative spurious correlation existed: bigger companies both employed relatively young management teams and were more innovative. Generally, then, it appears that older teams are more hesitant in taking diversification risks, but not in taking innovation risks. A possible explanation may be that diversification is perceived strategically riskier because it leads the organisation further from its established safe core domains than does innovation.

Average tenure on the team

The influence on performance of the time a certain (relatively) fixed group of people has worked together, is usually measured by taking the members' average team tenure. As people work together for a longer period of time, several related social

\footnotetext{
${ }^{1}$ As a matter of convenience, a rather sharp distinction is made here between "old" and "young" teams as measured by their average chronological age. As with all "average effects" theory is largely an extrapolation of what is known at the individual level. Therefore, in describing the "pure" effects of high versus low age in teams, we have to implicitly assume spread to be low. This is a frequent but seldom acknowledged assumption in most studies.
}

2 Of course, the entrepreneurial type of diversification is meant here, as the kind of diversification inspired by portfolio considerations is intended only to reduce risk. 
processes begin to affect group behaviour and especially communication. Katz (1982) suspected these tendencies in communication to play an important mediating role in the typical curvilinear relationship between average team tenure and project group performance that was found in previous research (Pelz \& Andrews, 1966; Smith, 1979): at first average team tenure seems to enhance team performance, but after a certain (optimal) point, it depresses performance. Four processes are thought to occur as teams work together for a longer time. First, as groups start to structure their work, they will eventually develop standard work patterns or routines (Weick, 1979), that are predictable and comfortable to them. Groups will thus exhibit increasing behavioural stability over time. Moreover, with increasing group longevity, group members will tend to increasingly close off towards information that threatens to disrupt their comfortable and predictable practices and patterns of behaviour (Staw, 1977). Second, long-standing membership leads to a phenomenon called selective exposure (Rogers and Shoemaker, 1971). This is a tendency for group members to communicate only with those whose ideas and viewpoints are in accord with their own interests and current perspectives. Outside messages and information conflicting with their established practices and dispositions are more likely to be avoided. Third, a relatively long history of shared experiences and socialization is likely to bind the group together by providing similar frames of references. Therefore, as team members continue to interact over time, the set of understandings about the group and its environment will become more homogeneous (Salancik and Pfeffer, 1978). Burke and Bennis (1961) showed, that consensus with one another increased among team members interacting over a longer period of time. All this has a positive influence on the group's sense of identity, but it will also demarcate the group more sharply from other groups in the organisation. Consequently, the quantity and quality of inter group communication is likely to decrease with team longevity. Fourth, as team members work together for a long time the tasks they have to perform, are likely to be accomplished using a division of labour or role differentiation that is increasingly well tuned to members' individual strengths and weaknesses. Each member knows what to expect from others, and what is expected of him. This lowers the immediate necessity of task-related talk and interaction among team members (Porter, Lawler and Hackman, 1975). Taken together, over time interactions among team members and with members of other teams, are expected to decrease. In an important study among $50 \mathrm{R} \& \mathrm{D}$ project groups, Katz (1982) tested the above predictions concerning the effect of group longevity on communication and performance. He found empirical support for the increased "closing off" of longer tenured teams from key information sources both within and outside their groups. Communication appeared to be significantly less in high-tenured teams as opposed to short-tenured teams. In fact, with regard to contacts outside the project group, a curvilinear association was detected, indicating an initial increase and subsequent decrease in outside communications with increasing team tenure. More importantly, Katz did find these communication patterns to mediate the relationship between team age and team performance. Specifically, performance was curvilinearly related to team age because communication rose and fell with increasing team tenure. In explaining the form of this relationship, it is argued that in low tenure regions team building and learning promote performance as team members contribute fresh ideas and get to know each other's strengths better. After a certain amount of time however (about 2,5 years in Katz' study) high longevity teams tend to "settle down", rely on routines and decrease overall communication. As a result performance deteriorates. That is: his study demonstrates "the important role group longevity and its underlying social processes can play in influencing the information processing behaviours of project group members which, in turn, affect project performance" (Katz, 1982; p.98).

From the empirical overview (see Appendix) ${ }^{3}$, it is clear that few researchers had a close look at TMT longevity as an influencing variable on performance. The positive effect team tenure has on strategic change, was not expected by Wiersema and

${ }^{3}$ In quoting empirical TMT research into this relationship, authors (e.g. Smith et al., 1994) sometimes erroneously refer to studies that do not as a matter of fact deal with team tenure, but rather with the average organizational tenure of members within the team. In our empirical overview (see Appendix) we only mentioned studies that explicitly dealt with the average tenure of members on the team. 
Bantel (1992). Instead, they drew on Katz (1982) in hypothesizing lower communication levels and consequently higher resistance to change in longer tenured teams. Possibly, they speculate, team longevity fosters social integration and more effective communication which in turn promotes performance. The positive effect on group dynamics and change seems to taper off, however, at higher levels of team tenure, indicating that, over time, teams in frequent interaction develop towards the "optimal" smooth group dynamics that ease strategic change. Eisenhardt and Schoonhoven (1990) discovered a strong positive effect of the joint prior work experience of founders on the success of new ventures. Again referral is made to heightened familiarity, cohesiveness and communication quality among groups having experience in working together. Finally, Smith et. all.(1994) did not find any of the expected effects of team age.

On balance, then, results on TMTs are not very clear. Two studies do find a positive effect of average team tenure while another does not. However, these results may very well hide the curvilinear relationship established so often in other group research. Regrettably, this relationship is not explicitly tested in any of the TMT studies. Moreover, authors are often unclear about the units of measurement and ranges of their average measures, making it difficult to compare results of studies. Still, this drawback seems characteristic of TMT research in general.

\section{Average tenure in the organisation}

Long organisational tenures may be seen as the outcome of a self-selection process by which those adhering to the organisations' norms and perspectives are willing or allowed to stay in the firm (Pfeffer, 1983). Longer tenured managers are therefore more committed to the organisations' ways (Wanous, 1980), show higher commitment to the status quo (Stevens et al., 1978; Staw and Ross, 1980) and to the values of the firm (Schmidt \& Posner, 1983). With organisational tenure, managers' rigidity and commitment to established policies and practices increases (Katz, 1982; Hambrick et al., 1993) as an action repertoire is built up over time that promotes behavioural stability (Finkelstein and Hambrick, 1990). Ever more reliance is put on experience instead of on new stimuli (Katz, 1982) and resistance to change and risk-aversion may become politically or emotionally motivated because of vested interests (Salancik, 1977; Miller and Friesen, 1980). Generally, then, some kind of conservatism in strategies and policies is expected. Empirical team results (see Appendix) demonstrate this conservatism of long tenured TMTs in three studies. Finkelstein and Hambrick (1990) found that higher average organisational tenures led firms to be more persistent and inflexible in their strategies. Moreover, these firms appeared to follow "middle of the road" strategies closely resembling those of competitors, resulting in performance levels close to industry averages. Similarly, Wiersema and Bantel (1992) find the amount of corporate strategic change to be related to low average organisational tenure. This apparent conservatism, however, does not necessarily lead to lower levels of innovation (Bantel and Jackson, 1989) or lower performance. To the contrary, perhaps, as Hambrick and D'Aveni (1992) show in a matched sample of surviving and failing firms. Bankrupts' TMTs appeared to have lower and declining average organisational tenures in the years preceding their failure than their surviving counterparts, reflecting the higher turnover rate in this period. However, bankrupts' organisational tenures were already significantly lower five years before failure and it is doubtful whether this signals lower managing qualities of short tenured teams. More probably, it simply reflects the turmoil (scapegoating, replacements or voluntary departures) that are a well-known tendency in troubled organizations (Hambrick and D'Aveni, 1992). Michel and Hambrick (1992) find a tendency for longer tenured TMTs to lead companies with a high degree of interdependence in business unit diversification. This result was expected as the integration, coordination and (especially) communication skills needed to manage interdependencies across business units would be fostered by more cohesive groups, allegedly TMTs with high organisational tenures. However, nor TMT organisational tenure, nor its interaction with the degree of interdependence appeared to affect performance. So we can conclude that high organisational tenure TMTs tend to be rather conservative with regard to strategic choice and flexibility, leading to quite average results. 
Average tenure in the industry

Just like high organisational tenure, long tenures in a certain industry built shared interpretations and policy preferences that form a kind of 'industry wisdom'. Several studies have shown the existence of these kinds of 'industry recipes' to managing a company within the industry (Spender, 1989; Hambrick et al., 1993). As their industry tenure rises, managers show an increasing psychological adherence to these industry specific frames of reference. Therefore, they take on an increasingly prominent position in managers' views on current problems. Despite the potential value of this in-depth industry familiarity (Gupta, 1984), too much industry experience may, just like organisational experience, restrict managers' awareness of alternatives and lead to 'conservative' policies close to industry standards. This point was clearly demonstrated in a study by Hambrick et al. (1993) who did indeed find a strong association between industry tenure and top executives' commitment to the status quo concerning their organisations' future policies and leadership. Interestingly, the effect of industry tenure on commitment to the status quo appeared stronger than and independent of that of organisational tenure, suggesting a distinctive impact of industry experiences on conservatism. Unfortunately, the authors only report a small and insignificant positive simple correlation between CEO industry tenure and performance. Their call for team level research in this area has not yet been followed; consequently there is no empirical material to report on. Based on the foregoing, it does however make sense to expect average industry tenure to have similar effects as organisational tenure.

Average educational level

An individual's level of education reflects its cognitive abilities and skills. As such, it was shown to be positively associated with tolerance for ambiguity and information processing capacity (Schroder, Driver and Streufert, 1967; Dollinger, 1984). Because of this, higher educated people may be expected to "generate (and implement) creative solutions to complex problems" (Bantel and Jackson, 1989: 110) and indeed higher managerial education level appears consistently associated with the receptivity to innovation (Becker, 1970; Rogers and Shoemaker, 1971; Kimberly and Evanisko, 1981). These findings have inspired team researchers as well (see Appendix). Bantel and Jackson (1989) found innovation to be greater in banks headed by more educated TMTs. Similarly, the mean educational level of a team appeared to be the strongest demographic predictor of strategic change in an heterogeneous sample of US manufacturing companies (Wiersema and Bantel, 1992). It may be speculated from this, that higher average educational levels on a team make it more prone to undertake highly consequential strategic decisions that help ensure survival in the long run. A (direct) connection between educational level and performance, however, was not researched.

Main functional expertise

Although a categorical variable like functional experience cannot be averaged (just like, for instance, race or nationality), teams can be rated according to the relative dominance of certain functional expertise represented in a team. Various studies in the strategy literature have shown that different strategies may require different functional skills for successful implementation (Hitt, Ireland and Palia, 1982; Snow and Hrebiniak, 1980). For instance, Gupta and Govindarajan (1984) reasoned that "build" strategies, required a managerial competence at monitoring and analysing external industry characteristics like consumer needs and competitor strategies; competencies that are relatively more typical of managers with functional experience in marketing and sales. "Harvest" strategies on the other hand require skills to improve internal efficiency. Thus, the hypothesis was formulated that general managers with experience in marketing and sales would be more successful in implementing "build" rather than "harvest" strategies. This was indeed the case; moreover, implementation of harvest strategies even appeared to be hampered by managers' marketing or sales backgrounds. A match between managers' functional expertise and the required 
strategic expertise was also found by Song (1982) and Chaganti and Sambharya (1987). In the former study, CEOs of companies diversifying through internal growth had mainly followed marketing and operations careers, whereas the CEOs of acquisitive diversifiers tended to have finance, accounting and law backgrounds. Chaganti and Sambharya (1987) analysed the functional make-up of the dominant coalitions of a prospector, analyser and defender in the US tobacco industry. As expected, the dominant coalition of the prospector firm had a higher percentage of executives with R\&D and marketing backgrounds than the analyser and defender firm; the defender firm employed the highest percentage of finance-oriented executives.

To date, only two studies into the effects of core functions represented in the TMT exist. Michel and Hambrick (1992) expect teams managing more interdependent business units to need a higher proportion of top managers that understand the substantive rather than the strictly financial or administrative implications of their decisions. This understanding, they expect, is brought by core operational areas like marketing, operations and R\&D. The results of their analysis supports the contention that more interdependent businesses were led by teams with more core functional expertise. However, contrary to expectation, this match produced worse instead of better results, something the authors have difficulty in explaining. Hambrick and d'Aveni (1992) take a related point of departure. They stress the general importance of so-called 'core functional area's' like design, production and marketing in the survival of firms. Experience in these area's, it is argued, ensures executives with "hands-on" competencies that staff fields like accounting, finance, law and personnel do not provide (Hayes and Abernathy, 1980; Hambrick and D'Aveni, 1992). As compared to survivors, bankrupts did indeed have lower and declining levels of core functional expertise in their teams as they approached failure. It appears, then, that given the specific tasks of a TMT team, a matching amount of core expertise may prove critical in handling situations appropriately.

\subsection{Experience variety}

As discussed in section 2.2, two opposing viewpoints exist as to the normative effects of team diversity. On the one hand diversity offers more diverse resources to confront complex problems. On the other hand it wastes resources: dissimilar people have more difficulty in working together because they lack common ground. An important moderator in determining the performance impact of diversity is the state of the environment. In complex and changing circumstances, diversity may have a premium, whereas in stable conditions homogeneity seems preferable. These main and moderated effects will be recurrent in the empirical experience variety studies below.

Age variety.

People' outlook on the world is greatly determined by the historic events and societal values during their formative years (Eisenstadt, 1956). People from similar age cohorts are therefore likely to share important frames of reference inherited from their past, but present experiences in the present are also likely to be similar. For instance, employees of the same age share the experience of important historical events (e.g. wars, crises, social developments), and are now probably raising children of the same age or tend to have other similar events occurring in their family lives. Shared biographies produce a shared language, including a common vocabulary and interpretation of events concerning a wide range of non-work-related issues (Ryder, 1965). Because of these language compatibilities, people who share demographic attributes (in this case age) communicate more frequently (Byrne, 1969; Pfeffer, 1983; Zenger \& Lawrence, 1989). They feel attracted to each other more and form more cohesive groups (Lott and Lott, 1965; Good and Nelson, 1971) which will generally lead to enhanced team performance (Shaw, 
1981; Mullen and Copper, 1994; Smith et al., 1994) ${ }^{4}$. Teams of dissimilar age lack these integrating forces and are likely to run into communication problems that may result in power struggles, conflict (Pfeffer, 1983) and, ultimately, turnover. O'Reilly et. all (1989) even report a direct positive effect of group age heterogeneity on turnover: the relationship was not mediated by worsened social integration. ${ }^{5}$

In empirical TMT research (see Appendix), two studies were concerned with these turnover effects. Wagner et. all. (1984) find a negative influence of individual age distances on the likelihood of individuals to stay in the team, a result that is in line with theory in that age similarity fosters interpersonal attraction and thus the likelihood of staying. The stimulating effect of TMT age heterogeneity on turnover was particularly strong in a sample of Japanese TMTs (Wiersema and Bird; 1993) allegedly because of Japanese' higher (cultural) sensitivity to interpersonal differences. Interestingly, in the TMT literature, age heterogeneity is also expected to provide the variety of perspectives that may enhance innovation and strategic change. However, neither of the two studies on this issue (Bantel and Jackson, 1989; Wiersema and Bantel, 1992) could detect these expected effects.

We conclude that age heterogeneity promotes turnover both at the individual and at the team level. A positive effect on strategic change and innovation was not found. No study directly examined the effect on organisational performance. However, as TMT turnover tends to precede (and follow) bad organisational performance (Hambrick and D'Aveni, 1992), it may be speculated that age heterogeneity is ultimately associated with low performance through its effect on turnover.

Team tenure variety

Homogeneity of tenures on the team suggests a shared socialization and group experiences that reinforce cohort effects (Wiersema and Bantel, 1992) including heightened cohesiveness and lower turnover. O'Reilly et al.(1989), for instance, show that team tenure homogeneity of work groups increases group level social integration, which in turn, restricts turnover in the team.

TMT studies (see Appendix) were mostly concerned with these positive effects of team tenure diversity on turnover. Although the effect did not materialize in a US context study (Wiersema and Bantel, 1993) a study among Japanese TMTs (Wiersema and Bird, 1993) did show a strong positive impact of team tenure diversity on team turnover. According to Wiersema and Bird (1993) this is caused by a greater attention and sensitivity to differences among Japanese TMTs because they are substantially more homogeneous than US TMTs. What is more, Japanese' collectivist cultural values are likely to encourage conformity and heighten sensitivity to own and others' differences. Only Wiersema and Bantel (1992) formulated and tested an alternative expectation favouring heterogeneity of team tenures. They hypothesized that team tenure homogeneity leads firms to undertake less corporate strategic change, as it provides a group with less variety of information sources and outlooks to act upon. However, no support for this hypothesis was found. We can conclude that team tenure homogeneity tends to increase social integration and lower member turnover. Variety of team tenures does not seem to enhance strategic change.

Organisational tenure variety

${ }^{4}$ This will only hold if the group's norms are set to high performance; otherwise even the opposite may occur (Shaw, 1981)

${ }^{5}$ Surprisingly, individual distance in age to other team members lowered individual turnover, that is: more distant members were less likely to turn over. This finding remains ill understood. 
Just like people of the same age cohort share life experiences, people of the same organisational cohort share many organisational experiences that over time lead to the development of similar beliefs and perspectives on the firm and how it operates (Pfeffer, 1983; Tushman and Romanelli, 1985; Wagner et al., 1984) This set of perspectives can be thought of as an organisational paradigm that is more congruent within groups of similar dates of entry. This congruence among organisational members on a team enhances interpersonal communication (Zenger and Lawrence, 1989) and cohesion (Lott and Lott, 1961; Katz, 1982). However, too much homogeneity may ultimately lead to groupthink (Janis, 1972): an urge to maintain good intragroup relations at the cost of realistic and critical appraisal of alternatives. This critical spirit is more likely to be maintained in a somewhat heterogeneous team, pooling long and short tenured people to provide more diverse opinions. Moreover, members who joined the organisation at different times often have different technical skills and views on the organisation. The diverse pool of these inputs may in fact improve the probability that a group will generate diverse and innovative solutions (Ancona and Caldwell, 1992) that lead to higher quality decisions (Wanous and Youtz, 1986). Thus, organisational tenure diversity is likely to influence group processes and outcomes in different ways.

In fact, this compositional variable is among the most popular ones studied in empirical TMT research (see Appendix). Michel and Hambrick (1992) expect homogeneous TMTs to head firms having strongly interdependent business unit diversification postures. Homogeneity of tenures is thought to promote cohesion and high quality of in-group communication that are in turn deemed necessary to manage interdependencies. In contrast to this hypothesis, they find that organisational tenure heterogeneity is associated with high interdependence. This unexpected result is very attributed to a higher need for team continuation in high interdependence firms. This would be facilitated by staggered team membership around a high team tenure mean. In their own words, this would "[e]nhance stability and provide opportunities for the mentoring and grooming of heirs. The team recreates itself slowly, gradually engendering commitment to a core business, shared perspectives and perpetuation of a given strategy" (Michel and Hambrick, 1992: 30). We feel this is a rather far-fetched explanation where a much simpler alternative exists: managing high interdependence calls for the more varied repertoire of experiences in a heterogeneously tenured team. Anyway, the direct relationships with performance of firms, nor the interactions between interdependency and heterogeneity were significant.

As to the expected higher turnover among teams with heterogeneous organisational tenures, two studies are of interest. Wagner, Pfeffer and O'Reilly (1984) do indeed find the expected result in a US sample of TMTs. However, in the Japanese firms study by Wiersema and Bird (1993) organisational tenure heterogeneity is in fact the only temporal heterogeneity measure that does not have a (direct) effect on team turnover. The lack of significance for organizational tenure heterogeneity was caused probably by its association with a control variable, mean team age, which had a strong negative impact on turnover in Japanese firms. The latter is counter intuitive from a Western point of view and possibly reflects good job switching opportunities for young Japanese employees and/or a reluctance of incumbent dominant coalitions to share power by promoting young managers.

The idea that diverse tenures may promote creativity is reflected in two studies searching for a link with innovation (Bantel and Jackson, 1989) or strategic change (Wiersema and Bantel, 1992). However, neither study found heterogeneous organisational tenures to predict more innovation or corporate strategic change, possibly because organisational tenure heterogeneity does not adequately capture the underlying construct of creativity and information diversity. Finally, three studies linked organisation tenure heterogeneity to corporate performance. Hambrick and d'Aveni (1992) found no difference in organisational tenure heterogeneity between survivors and bankrupts in the five years preceding failure, suggesting that this kind of heterogeneity is not associated with organisational decline nor with its successful management. Smith et al. (1994) did find a negative direct effect of TMT experience heterogeneity ${ }^{6}$, on the return of investment of high-technology firms, possibly

${ }^{6}$ In fact, Smith et al. (1994) used a composite measure of industry and organizational tenure heterogeneity (alpha $=.62)$, called experience heterogeneity. 
indicating distracting and time-consuming conflict in these teams. New support was also found for the negative relationship between tenure heterogeneity and the amount of informal communication within the team. The third study, by Haleblian and Finkelstein $(1993)^{7}$ again revealed a negative association between organisational tenure heterogeneity and a composite measure of firm performance. As can be expected, the relationship was most pronounced in the high discretion (computer) industry.

To summarize the above, heterogeneity of organisational tenures affects the team process mainly through more difficult communication, integration and (at least in Western countries) increased turnover. As to the eventual organisational outcomes, however, evidence is mixed. The influence this type of TMT variety on performance is at best neutral: it ranges from zero in case of survival chances to negative in case of financial economic measures. In addition, no association between organisational tenure heterogeneity and strategic decisions like change and innovation seem to exist.

Industrial tenure variety

As discussed in the section on average industry tenure effects, experiences within an industry also tend to mould one's views on how (all) companies within it should be managed; consequently industrial paradigms may develop. As with the other variety effects, heterogeneity of industry tenures and experiences may lead to different interpretations and conflict whereas homogeneity fosters interpersonal understanding and cohesion. Industries in a rut, may however benefit from frame-breaking insights typically developed by more heterogeneous teams within the industry. However, these kinds of hypotheses on industrial tenure heterogeneity were never empirically tested in TMT settings.

\section{Educational background variety}

In contrast to the preceding variables, educational tracks measure cognition more directly because of a self-reinforcing choice and training process. Educational choice's person's makes reflect their personalities, attitudes and cognitive styles (Holland, $1973 ; 1985)$. In turn, the chosen curriculum further shapes perspectives and outlooks in line with the professional profile it seeks to produce. Thus, whereas in case of age or tenure we have to infer a lot as to what attitudes it produces, educational tracks and their content are known and people graduating will be fairly homogeneous in the professional attitudes and outlooks they were taught (which is a lot more difficult to say from life or organisational experiences). A TMT with diverse educational backgrounds (e.g. arts, sciences, business, engineering etc.) may be expected to benefit from these varying perspectives taken by its members, but it should again be mindful of the strains that the integration of various perspectives is likely to produce on the group process (Pfeffer, 1983). However, in a TMT study by Wiersema and Bantel (1983) the expected negative effect of educational diversity on turnover did not materialize (Wiersema and Bantel, 1993). Other empirical TMT research (see Appendix) has generally been rather mixed. The expected positive influence of educational heterogeneity on dynamic strategic choices was found for strategic change (Wiersema and Bantel, 1992), but not in case of innovativeness (Bantel and Jackson, 1989). As to performance, Smith et al. (1994) find a positive direct effect of the heterogeneity in TMT years of education on both ROI and sales growth and (again) no relation with process variables (communication and integration). This result supports the creativity argument that may be expected to be particularly influential in dynamic industries. However, note that Smith et al. are actually measuring some kind of educational tenure heterogeneity, which does not necessarily imply a broad scope of

${ }^{7}$ In this study, organizational tenure heterogeneity is included only as a control variable "[t]o control for team effects and to ensure that the power distribution and team size variables were not confounded" (Haleblian and Finkelstein, 1993: 854). As to its effect on performance no expectation is stated. 
different educational tracks ${ }^{8}$. We should therefore treat this result cautiously and can only conclude that educational differences do not particularly hamper group processes and may have direct positive effects on performance and the propensity to strategic change.

Functional background variety

In a similar way as educational tracks, time spent in a particular department or function is likely to lead to the development of a viewpoint consistent with the activities and goals of that department or particular function. As a result, the usual problems and benefits of diversity would arise in varyingly composed groups. Empirical evidence on the effects hereof on performance, however, is mixed. Ancona and Caldwell (1992) found functionally diverse new product teams to perform worse, possibly because of social integration or communication difficulties that relate to function-specific frames of reference. To test their existence, Dearborn and Simon (1958) presented managers with a complex business case and found that "[e]ach executive will perceive those aspects of a situation that relate specifically to the activities and goals of his department" (op. cit.: 142) So selective perception in the identification of company problems arises. However, in an extended conceptual replication of Dearborn and Simon's study by Walsh (1988) the former's results are severely doubted as managers do not appear to suffer from 'impoverished world views or parochial information use' (op. cit.: 887) that reflect their functional area of management. Instead, the average manager appeared very capable to identify problems and use information across five functional domains. Based on these results then, we would not expect functional TMT homogeneity to lead to one-sided team views on problems. Nor would heterogeneous functional teams have substantial problems in integrating, communicating and performing, as Ancona and Caldwell (1992) suggested. In short, we would not expect any particular effect from functional diversity. Nevertheless, empirical TMT studies (see Appendix) keep basing their hypotheses on presumed integration difficulties, although without much success. Smith et al. (1994) find no effect at all of functional TMT diversity on team processes or firm performance. A marginal negative effect is found by Haleblian and Finkelstein (1993) but only in those contexts where managerial discretion is high. Michel and Hambrick (1992) also found no effect of functional diversity on the performance of diversified firms.

Summarizing this TMT research then, we conclude that functional diversity does not influence performance much.

Temporal and background variety

One empirical study by Murray (1989: see Appendix) is discussed separately as it combines several spread variables in two heterogeneity indexes, called temporal heterogeneity (age, team and organisational tenure) and background heterogeneity (functional and educational experience). As hypothesized, temporal heterogeneity is positively related to (adaptability-based) long-run performance, but no significantly negative association was found with (efficiency-based) short-run performance. Apparently, short-run performance is very hard to predict from demographic data. This may be supportive of previous findings (Weiner and Mahoney, 1981) that management contributions to short-run performance tend to be dominated by external circumstances. Moreover, the effects only materialize in the oil business and not in the food business sub sample, probably because success criteria in the latter are more determined by the marketing department than by the TMT. Contrary to temporal heterogeneity, background heterogeneity was no significant predictor of either long or short-run performance.

${ }^{8}$ Wiersema and Bantel even report a negative simple correlation between educational curriculum heterogeneity and their control variable firm performance. 


\subsection{Summary of average and variety effects}

Averages and spreads of various demographic variables in teams have been used to predict several organisational phenomena ranging from turnover in the team itself to innovation, strategic change and performance. However, the results are far from consistent and very often fail to reach significance. Table 1 summarizes the number of studies and hypotheses regarding the demographic variables encountered, the percentages confirmed effects, no effects and counter hypothesized effects.

\section{INSERT TABLE 1 ABOUT HERE}

As can be seen, the record is not very impressive as results are ridden with non-findings and even counter hypothesized findings. Average experience appears most promising in the area of organizational, educational and functional experience. In particular, low organizational experience and high education levels tend to be associated with organizational change and innovativeness, whereas core functional expertise seems to be of general importance. Average age and team tenure are generally weak predictors of organizational phenomena.

In the realm of variety effects, the record is even worse. Findings are inconsistent (for instance regarding the effect on team turnover) and difficult to relate to each other. Even for the most frequently studied organizational tenure variety variable, only 4 out of 13 hypothesized relationships could be confirmed. Overall, it is fair to conclude that although many serious attempts have been undertaken to relate team demography to team outcomes and individual studies are sometimes successful in finding one or two significant relationships, the results lack coherence between and often even within studies. In the next section we will try to explain what features of research thus far may be responsible for this bad record and we set forth possible remedies and extensions in future research.

\section{Discussion}

The present section will discuss the empirical TMT research to date in relation to the upper echelons model of figure 2 . In doing so, several limitations of current research will be identified along with possible extensions. First we will deal with the theoretical foundation of the TMT studies. Second, a number of empirical issues will be raised.

\subsection{Theory (development)}

From the perspective of the upper echelons model as a whole, the first thing that clearly characterizes empirical research to date is fragmentation. Different authors tend to deal with different parts of the upper echelons model, linking averages and spreads of TMT characteristics to various strategic choices, processes and performance measures. The result, as stated above, is a rather confusing set of (mostly unique) TMT research findings in various parts of the model, that are difficult to integrate in one clear and coherent picture.

A second, related point is the length of the causal chain explored. The upper echelons model clearly specifies a three- step chain from team characteristics, through choices and/ or processes to performance. Most TMT research however only links inputs to outputs based on an inferred intermediate (choice) process that is not actually measured. Little is known consequently, of how the effects are produced. In the studies reviewed here only the one by Smith et al. (1994) captures the entire causal chain by including three process variables. The model thus formed explains 56 and 44 percent of total variance in ROI and sales growth respectively. To the present author's knowledge, no empirical study yet exists that includes the whole model including strategic choices. 
Third, in team studies competing theoretical expectations may exist as to the effect of certain variables (Hambrick and D'Aveni, 1992) especially when it comes to the impact of team variety. Few authors (e.g. Murray, 1989; Finkelstein and Hambrick, 1990) however handle this issue properly by either specifying alternative hypotheses, specifying curvilinear relationships (e.g. Katz, 1982) or by including moderator variables to account for different effects under different circumstances. Because of this, many non-findings remain unexplained that may in fact be due to imprecise specification of relationships or circumstances under which effects should or should not materialize. For instance, variety on a team potentially provides many perspectives on solving new problems with which the team has no experience yet. On the other hand, it hinders communication and social integration as different people tend to hold different frames of reference and people generally prefer dealing with likes. It now depends on the group's task or the circumstances under which it is to perform its task, which of these effects will take most prominent effect. In stable environments with routine problems, heterogeneity on a team is less warranted and its destabilizing role on social functioning is likely to dominate and undermine performance. In more dynamic environments with non-routine problems to be solved, heterogeneity may provide the needed breadth of perspective to arrive at an innovative solution. Inter-individual differences are less damaging as they are interpreted and used productively to the task. In a similar way, time pressure can prompt a team to acknowledge the need to set aside personal dislike and mistrust and turn heterogeneity from a negative to a positive influence on team performance. Inclusion of interaction variables like for instance task characteristics, environmental dynamism or time pressure does more justice to the situational specificity of demography effects and may heighten the explained amount of variance in the dependent variables.

A fourth important limitation of existing studies is their crude treatment of the individual choice process by using demographic variables. In essence, people with certain demographic characteristics are supposed to be rather homogeneous in holding certain attitudes, traits and values that assumingly lead to a particular behaviour. These attitudes and values are, however, seldom measured and neither are their relationships with demographics. This obscures the exact mechanism by which demographics influence behaviour, leading to rather speculative conclusions when expected results do not show up. We will illustrate our point with an example by Hambrick and Mason (1984: 201). The authors quote research suggesting that managers from lower socio-economic origins tend to pursue more diversification and acquisition. They do this "presumably in order to achieve recognition and esteem" (op. cit., p. 201; emphasis added). However, when Hambrick and Mason translate this finding to TMTs they stick to the simple association between background and diversification. Whether high needs for esteem do indeed lead to diversification thus remains unclear. Similarly, whether managers' social class backgrounds are indeed related to need for esteem in a particular sample remains unknown'. Instead, a more distant (assumed) proxy of need for esteem (i.e. socioeconomic background) is used. In addition, or even worse, the inferred behavioural implications of many demographic variables can be very diverse, each having distinct and sometimes conflicting performance implications. For instance, higher average age is often taken to represent more experience. It might, however, equally well signal conservatism or even physiological (especially memory) deterioration that hinders performance and it has indeed been used in that sense. We suspect that many nonfindings in upper echelons studies are at least partly caused by this use of rather distal proxies (demographics). A research field that is so fragmented and ridden with non-findings (52\% in the reviewed literature) may therefor benefit from going one step back in the causal chain by measuring managers' (pre)dispositions, for instance their personality, more directly and linking these to their behaviours, choices and, ultimately, performance in a team. Thus, a focus on more fundamental behavioural tendencies rooted in personality seems warranted because these are more directly linked to behaviour and provide a more valid measurement of values and attitudes than do demographic variables. In fact, this is a crucial point that Hambrick and Mason

\footnotetext{
${ }^{9}$ This is important from a normative point of view. In screening candidates for an important acquisition function, should an applicant be interviewed and tested to gauge his need for esteem or simply asked to state his father's income?
} 
(1983) readily acknowledged. When they presented the model and called for empirical research they made it very clear that "[I]t is doubtful that this research stream can progress far without greater attention to relevant literature in related fields, especially psychology and social psychology" (Hambrick and Mason, 1984: 203). Their emphasis on 'observable' characteristics to start with, was inspired by rather practical reasons like data availability and measurability. However, the growing need to use more psychological variables in upper echelons research is repeatedly stressed by researchers in the field. For instance, Hambrick et al. (1993: 402) state that "[E]ven though psychological factors (...) are of central significance to upper echelons theory, such phenomena are rarely studied or measured directly in empirical inquiries of top executives". Indeed, we know of no empirical upper echelons study to date that has explicitly looked at the psychological composition of the team. In fact this seems to be a void even in the broader field of organizational diversity (Milliken and Martins, 1996).

A final limitation of the upper echelons model is its simplicity in dealing with the strategy concept itself. One aspect of this problem was already mentioned above: the importance of interaction variables on the causal links in the model is too seldom acknowledged. Moreover, the eagerness to predict specific strategic choices from demographics causes a complete lack of attention to the importance of strategy making and implementation. That is: to the process of configuring repertoires of actions, to the consistency of strategies both internally and over time and to the proper implementation of these strategies. Finally, the dynamic processes of strategic adjustments and reactions over time have been completely overlooked. In many industries the capacity to change or stick to a strategic course is vital, so a proper model that links choices to performance should include this element as well.

\subsection{Empirical issues}

Three limitations of empirical nature will be discussed. First, there is a problem in untangling the different effects of the average and variety of variables. Two teams that have the same spread (variety) in age, for instance, may have widely differing means. It is likely that relatively young diverse teams deal with this diversity differently than relatively (experienced) old teams. Conversely, two teams of equal average age can differ widely on the spread in those ages. Consequently, if one hypothesizes on the impact of high or low average age (for instance on innovativeness) one is implicitly assuming (but not ensuring!) low spreads around those means; otherwise the effect is likely to be 'diluted' by the more extreme team members. This problem of means and spreads is hardly acknowledged in the reviewed literature, where mean and diversity effects are simply treated separately. Anyway, if a methodology is applied that does not properly deal with this problem, results are essentially uninterpretable as one compares apples and oranges.

A second and related problem concerns the right measurement of variety in a team. Most authors refer to the classic overview of inequality measures by Allison (1978) when they choose the coefficient of variation (COV i.e. standard deviation divided by the mean) to measure spread in a team. The main reason they do this is the so-called scale-invariant character of this measure, which means that it not sensitive to multiplication of each members' score with a constant. This property of a spread measure is useful when we want to compare for instance an income distribution expressed in yen with one in dollars. Note that only relative positions are of interest when the COV is used, absolute positions are not. It is our contention that past team researchers have too easily gone along with the stress on scale invariant measures by (mainly) sociologists, without thinking too much about its relevance or applicability in their own field of study. As it happens, in our type of research absolute differences often $d o$ matter. This can be easily shown if we take two (four person) teams with the following tenure distributions: (1 234$)$ and $\left(\begin{array}{lll}5 & 10 & 15\end{array} 2\right.$ ). We think it is obvious that for instance integration problems because of different dates of entry are highest in the second team as they differ most in this respect. Still, both teams have the same COV (.45), so they would (incorrectly) be treated as equally diverse when this measure is used.

A third issue of empirical nature is the use of very heterogeneous samples in team research. In fact, many studies are cross sections of the Fortune 500: samples that vary widely in size, industry structure, market conditions, governance structures and 
other confounding variables for which adequate controls are seldom included. It is for this reason, that Hambrick and Mason (1984) stressed the need either to use single industry samples or matched pair designs. In order to gain more control over confounding variables, another strategy is offered by Wiersema and Bantel (1992: 115) when they propose to "[r]ely on more in-depth analysis, such as case studies and experimental research".

\section{Summary and conclusion}

Although much research has already been done to test various propositions of the upper echelons theory, no clear coherent picture emerges. This is mainly due to limitations in the way upper echelons research has been approached so far. These limitations are of both theoretical and empirical nature. Concerning theory and theory development, it was argued that research has been rather fragmented when viewed from the original upper echelons model. It has focussed on short causal links and has insufficiently dealt with the competing hypotheses theory sometimes gives rise to. Furthermore, there are interesting aspects of the model that have hardly been researched, such as psychological team composition and the development or adjustment of team strategic choices over time. On the empirical side, problems exist in the simultaneous treatment of means and spreads of variables and in the often inadequate control of confounding variables. 


\section{References}

Allison, P.D. (1978) Measures of inequality, American Sociological Review, 43: 865-880.

Ancona, D.G. and Caldwell, D.F. (1992) Demography and design: predictors of new product team performance, Organization Science, 3: 321-341.

Bantel, K.A. and Jackson, S.E. (1989) Top management and innovations in banking: does the composition of the top team make a difference?, Strategic Management Journal, 10: 107-124.

Becker, M. (1970) Sociometric location and innovativeness, American Sociological Review, 35: 267-304.

Belbin, R.M. (1981) Management teams: why they succeed or fail, London: Heinemann.

Blaylock, B.K. (1983) Teamwork in a simulated production environment, Research in Psychological Type, 6: 58-67.

Botwinick, J. (1977) Aging and behavior, New York: Spanger.

Brockner, J. (1992) The escalation of commitment to a failing course of action: toward theoretical progress, Academy of Management Review, 19: 39-61.

Burke, D. and Light, L.L. (1981) Memory and aging: the role of retrieving processes, Psychological Bulletin, 90: $513-546$.

Burke, R.L. and Bennis, W. (1961) Changes in perception of self and others during human relations training, Human Relations, 14: 165-182.

Byrne, D. (1969) Attitudes and attraction, New York: Academic Press.

Byrne, D., Clore, J.L.j. and Worchel, P. (1966) Effect of economic similarity-dissimilarity on interpersonal attraction, Journal of Personality and Social Psychology, 4: 220-224.

Carlsson, G. and Karlsson, K. (1970) Age, cohorts and the generation of generations, American Sociological Review, 35: 710718.

Chaganti, R. and Sambharya, R. (1987) Strategic orientation and characteristics of upper management, Strategic Management Journal, 8: 393-401.

Child, J. (1972) Organizational structure, environment and performance: the role of strategic choice, Sociology, 6: 1-22.

Child, J. (1974) Managerial and organizational factors associated with company performance - Part I, Journal of Management Studies, 11: 175-189. 
Cyert, R.M. and March, J.G. (1963) A behavioral theory of the firm, Englewood Cliffs, NJ: Prentice-Hall.

Dearborn, D.C. and Simon, H.A. (1958) Selective perception: a note on the departmental identification of executives, Sociometry, 21: 140-144.

Dollinger, M. (1984) Environmental boundary spanning and information processing effects on organizational performance, Academy of Management Journal, 27: 351-368.

Eisenhardt, K.M. and Schoonhoven, C.B. (1990) Organizational growth: linking founding team, strategy, environment, and growth among U.S. semiconductor ventures, 1978-1988, Administrative Science Quarterly, 35: 504-529.

Eisenstadt, S.N. (1956) From Generation to Generation: Age Groups and Social Structure, Glencoe, IL: Free Press.

Filley, A.C., House, R.J. and Kerr, S. (1976) Managerial process and organizational behavior, Glenview, IL: Scott Foresman.

Finkelstein, S. and Hambrick, D.C. (1990) Top-management-team tenure and organizational outcomes: the moderating role of managerial discretion, Administrative Science Quarterly, 35: 484-503.

Good, L.R. and Nelson, D.A. (1971) Effects of person-group and intra-group attitude similarity on perceived group attractiveness and cohesiveness, Psychonomic Science, 25: 215-217.

Gupta, A.K. (1984) Contingency linkages between strategy and general manager characteristics: a conceptual examination, Academy of Management Review, 9: 399-412.

Gupta, A.K. and Govindarajan, V. (1984) Business unit strategy, managerial characteristics, and business unit effectieness at strategy implementation, Academy of Management Journal, 27: 25-41.

Haleblian, J. and Finkelstein, S. (1993) Top management team size, CEO dominance, and firm performance: the moderating roles of environmental turbulence and discretion, Academy of Management Journal, 36: 844-863.

Hambrick, D.C. and D'Aveni, R.A. (1992) Top team deterioration as part of the downward spiral of large corporate bankruptcies, Management Science, 38: 1445-1466.

Hambrick, D.C. and Finkelstein, S. (1987) Managerial discretion: a bridge between polar views of organizational outcomes, Research in Organizational Behavior, 9: 369-406.

Hambrick, D.C., Geletkanycz, M.A. and Fredrickson, J.W. (1993) Top management commitment to the status quo: some tests of its determinants, Strategic Management Journal, 14: 401-418.

Hambrick, D.C. and Mason, P.A. (1984) Upper echelons: the organization as a refection of its top managers, Academy of Management Review, 9: 193-206. 
Hart, P. and Mellons, J. (1970) Management youth and company growth: a correlation?, Management Decision, 4: 50-53.

Hayes, R.H. and Abernathy, W.J. (1980) Managing our way to economic decline, Harvard Business Review, July-August: $67-77$.

Hitt, M.A., Ireland, R.D. and Palia, K.A. (1982) Industrial firm's grand strategy and functional importance: Moderating effects of teachnology and uncertainty, Academy of Management Journal, 25: 265-298.

Holland, J. (1973) Making vocational choices: a theory of careers, Englewood Cliffs, NJ: Prentice-Hall.

Holland, J.L. (1985) Making vocational choices: a theory of vocational personalities and work environments, $2^{\text {nd }}$ ed, Enlewood Cliffs, NJ: Prentice-Hall.

Hurst, D.K., Rush, J.C. and White, R.E. (1989) Top management teams and organizational renewal, Strategic Management Journal, 10: 87-105.

Janis, I.L. (1972) Victims of groupthink, Boston: Houghton Mifflin.

Katz, R. (1982) The effects of group longevity on project communication and performance, Administrative Science Quarterly, 27: 81-104.

Kimberly, J. and Evanisko, M. (1981) Organizational innovation: the influence of the individual, organizational and contextual factors on hospital adoption of technological and administrative innovations, Academy of Management Journal, 24: 689-713.

Lewin, K. (1948) Resolving Social Conflicts, New York: Harper \& Row.

Lewin, K. (1951) Field Theory in the Social Sciences, New York: Harper \& Row.

Lott, A.J. and Lott, B.E. (1961) Group cohesiveness, communication level and conformity, Journal of Abnormal and Social Psychology, 62: 408-412.

March, J.G. and Simon, H.A. (1958) Organizations, New York: Wiley.

Maznevski, M.L. (1994) Understanding our differences: performance in decision making groups with diverse members, Human Relations, 47: 531-549.

McCain, B.E., O'Reilly III, C.A. and Pfeffer, J. (1983) The effect of departmental demography on turnover: the case of a university, Academy of Management Journal, 26: 626-641.

Michel, J.G. and Hambrick, D.C. (1992) Diversification posture and top management characteristics, Academy of Management Journal, 26: 9-37. 
Miller, D. and Friesen, P.H. (1980) Archetypes of organizational transition, Administrative Science Quarterly, 25: 268-299.

Milliken, F.J. and Martins, L.L. (1996) Searching for common threads: understanding the multiple effects of diversity in organizational groups, Academy of Management Review, 21: 402-433.

Mullen, B. and Copper, C. (1994) The relation between group cohesiveness and performance: An integration, Psychological Bulletin, 115: 210-227.

Murray, A.I. (1989) Top management group heterogeneity and firm performance, Strategic Management Journal, 10: 125141.

O'Reilly III, C.A., Caldwell, D.F. and Barnett, W.P. (1989) Work group demography, social integration and turnover, Administrative Science Quarterly, 34: 21-37.

Pelz, D. and Andrews, F.M. (1966) Scientists in Organizations, New York: Wiley.

Pfeffer, J. (1983) Organizational demography, Research in Organization Behavior, 5: 299-357.

Porter, L.W., Lawler, E.E. and Hackman, J.R. (1975) Behavior in Organizations, New York: McGraw-Hill.

Porter, M. (1980) Competitive strategy: techniques for analyzing industries and companies, New York: The Free Press.

Rogers, E.M. and Shoemaker, F.F. (1971) Communications of Innovations: a Cross-Cultural Approach, New York: Free Press.

Ryder, N.B. (1965) The cohort as a concept in the study of social change, American Sociological Review, 30: 843-861.

Salancik, G.R. and Pfeffer, J. (1978) A social information processing approach to job attitudes and task design, Administrative Science Quarterly, 23: 224-253.

Schmidt, W. and Posner, B.Z. (1983) Managerial Values in Perspective, New York: American Management Association.

Schroder, H.M., Driver, M.J. and Steufert, S. (1967) Human Information Processing, New York: Holt Rinehart \& Winston.

Shaw, M.E. (1976) Group dynamics: the psychology of small group behavior, $2^{\text {nd }}$ ed, New York: McGraw-Hill.

Shaw, M.E. (1981) Group Dynamics: the Psychology of Small Group Behavior, $3^{\text {rd }}$ ed, New York: McGraw-Hill.

Smith, C.G. (1979) Age of R\&D groups: areconsideration, Human Relations, 23: 81-93.

Smith, K.G., Smith, K.A., Olian, J.D., Sims jr, H.P., O'Bannon, D.P. and Scully, J.A. (1994) Top management team demography and process: the role of social integration and communication, Administrative Science Quarterly, 39: 412-438. 
Snow, C.C. and Hrebeniak, L.G. (1980) Strategy, distinctive competence and organizational performance, Administrative Science Quarterly, 25: 317-336.

Song, J.H. (1982) Diversification strategies and the experience of top executives of large firms, Strategic Management Journal, 3: 377-380.

Spender, J.C. (1989) Industry Recipes: The Nature and Sources of Managerial Judgement, Oxford: Basil Blackwell.

Staw, B. and Ross, J. (1980) Commitment in an experimenting society: a study of the attribution of leadership from administrative scenarios, Journal of Applied Psychology, 65: 249-260.

Stevens, J.M., Beyer, J.M. and Trice, H.M. (1978) Assessing personal, role and organizational predictors of managerial commitment, Academy of Management Journal, 21: 380-396.

Vroom, V. and Pahl, B. (1971) Relationship between age and risk-taking among managers, Journal of Applied Psychology, 55: 399-405,

Wagner, W.G., Pfeffer, J. and O'Reilly III, C.A. (1984) Organizational demography and turnover in top management groups, Administrative Science Quarterly, 29: 74-92.

Walsh, J.P. (1988) Selectivity and selective perception: an investigation of managers' belief structures and information processing, Academy of Management Journal, 31: 873-896.

Wanous, J.P. and Youtz, M.A. (1986) Solution diversity and the quality of group decisions, Academy of Management Journal, 29: 149-158.

Weick, K.E. (1979) The social psychology of organizing, Reading MA: Addison-Wesley.

Weiner, N. and Mahoney, T.A. (1981) A model of corporate performance as a function of environmental, organizational en leadership influences, Academy of Management Journal, 24: 453-470.

Whitney, J. and Smith, R. (1983) Effects of group cohesiveness on attitude polarization and the acquisition of knowledge in a strategic planning context, Journal of Marketing Research, 20: 167-176.

Wiersema, M.F. and Bantel, K.A. (1992) Top management team demography and corporate strategic change, Academy of Management Journal, 35: 91-121.

Wiersema, M.F. and Bantel, K.A. (1993) Top management team turnover as an adaptation mechanism: the role of the environment, Strategic Management Journal, 14: 485-504.

Wiersema, M.F. and Bird, A. (1993) Organizational demography in Japanese firms: group heterogeneity, individual dissimilarity, and top management team turnover, Academy of Management Journal, 36: 996-1025. 
Zenger, T.D. and Lawrence, B.S. (1989) Organizational demography: the differential effects of age and tenure distributions on technical communication, Academy of Management Journal, 32: 353-376. 
APPENDIX

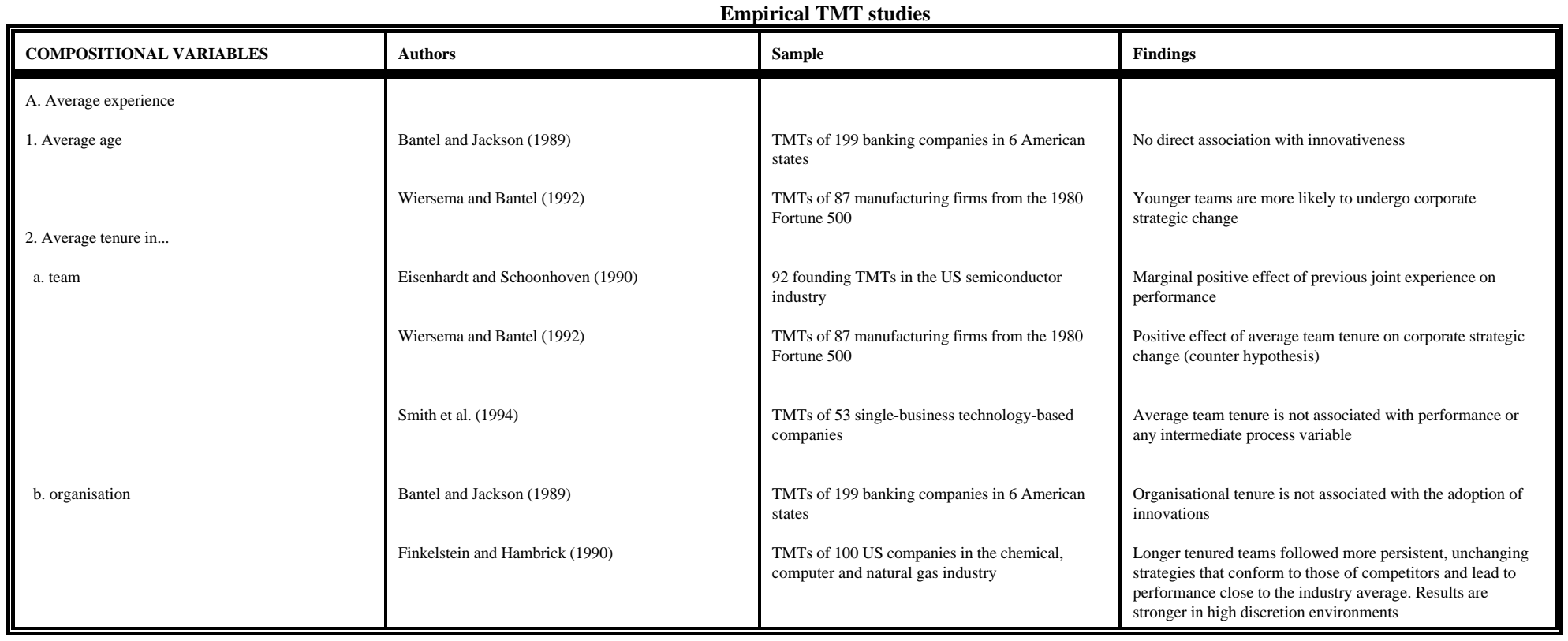




\begin{tabular}{|c|c|c|c|}
\hline COMPOSITIONAL VARIABLES & Authors & Sample & Findings \\
\hline \multirow[t]{3}{*}{ - continued- } & Hambrick and D'Aveni (1992) & $\begin{array}{l}\text { TMTs of } 57 \text { bankrupt and } 57 \text { surviving } \\
\text { companies in } 3 \text { industries }\end{array}$ & $\begin{array}{l}\text { Compared to survivors, bankrupts had lower and declining } \\
\text { average team tenures over a } 5 \text { year pre-bankruptcy period. }\end{array}$ \\
\hline & Michel and Hambrick (1992) & TMTs of 134 diversifying Fortune 500 firms & $\begin{array}{l}\text { TMTs organisational tenure is positively associated with the } \\
\text { amount of inter-dependence between firm units but hot } \\
\text { with performance. No interaction of tenure and } \\
\text { interdependence on performance. }\end{array}$ \\
\hline & Wiersema and Bantel (1992) & $\begin{array}{l}\text { TMTs of } 87 \text { manufacturing firms from the } 1980 \\
\text { Fortune } 500\end{array}$ & $\begin{array}{l}\text { Lower average organisational tenure is associated with } \\
\text { higher corporate strategic change }\end{array}$ \\
\hline \multirow[t]{2}{*}{ 3. Average educational level } & Bantel and Jackson (1989) & $\begin{array}{l}\text { TMTs of } 199 \text { banking companies in } 6 \text { American } \\
\text { states }\end{array}$ & $\begin{array}{l}\text { Educational level is positively associated with the level of } \\
\text { innovation }\end{array}$ \\
\hline & Wiersema and Bantel (1992) & $\begin{array}{l}\text { TMTs of } 87 \text { manufacturing firms from the } 1980 \\
\text { Fortune } 500\end{array}$ & $\begin{array}{l}\text { Educational level is positively associated with the amount } \\
\text { of corporate strategic change }\end{array}$ \\
\hline \multirow[t]{2}{*}{ 4. Main functional expertise } & Hambrick and D'Aveni (1992) & $\begin{array}{l}\text { TMTs of } 57 \text { bankrupt and } 57 \text { surviving } \\
\text { companies in } 3 \text { industries }\end{array}$ & $\begin{array}{l}\text { Bankrupts had lower and declining core functional } \\
\text { expertise over time }\end{array}$ \\
\hline & Michel and Hambrick (1992) & TMTs of 134 diversifying Fortune 500 firms & $\begin{array}{l}\text { TMTs in firms with high unit inter-dependence have more } \\
\text { corf functional expertise, but this lowers performance } \\
\text { (counter hypothesis) }\end{array}$ \\
\hline
\end{tabular}




\begin{tabular}{|c|c|c|c|}
\hline COMPOSITIONAL VARIABLES & Authors & Sample & Findings \\
\hline \multicolumn{4}{|l|}{ B. Experience variety } \\
\hline \multirow[t]{4}{*}{ 1. Age variety } & Wagner, Pfeffer and O'Reilly (1984) & $\begin{array}{l}599 \text { top management group members in } 31 \text { Fortune } \\
500 \text { companies }\end{array}$ & $\begin{array}{l}\text { Individuals that are more dissimilar in age from the rest of } \\
\text { the team are more likely to turn over }\end{array}$ \\
\hline & Bantel and Jackson (1989) & $\begin{array}{l}\text { TMTs of } 199 \text { banking companies in } 6 \text { American } \\
\text { states }\end{array}$ & Age heterogeneity is not associated with innovation \\
\hline & Wiersema and Bantel (1992) & $\begin{array}{l}\text { TMTs of } 87 \text { manufacturing firms from the } 1980 \\
\text { Fortune } 500\end{array}$ & $\begin{array}{l}\text { Age heterogeneity is not associated with corporate strategic } \\
\text { change }\end{array}$ \\
\hline & Wiersema and Bird (1993) & $\begin{array}{l}\text { TMTs of } 40 \text { Japanese firms from } 4 \text { industries listed } \\
\text { on the Tokyo Stock exchange }\end{array}$ & Age heterogeneity is positively related to team turnover \\
\hline \multicolumn{4}{|l|}{ 2. Tenure variety in... } \\
\hline \multirow[t]{3}{*}{ a. team } & Wiersema and Bantel (1992) & $\begin{array}{l}\text { TMTs of } 87 \text { manufacturing firms from the } 1980 \\
\text { Fortune } 500\end{array}$ & $\begin{array}{l}\text { No association between team tenure heterogeneity and } \\
\text { corporate change }\end{array}$ \\
\hline & Wiersema and Bantel (1993) & $\begin{array}{l}\text { TMTs of } 85 \text { manufacturing firms in the } 1980 \\
\text { Fortune } 500\end{array}$ & $\begin{array}{l}\text { Team tenure heterogeneity is not associated with team } \\
\text { turnover }\end{array}$ \\
\hline & Wiersema and Bird (1993) & $\begin{array}{l}\text { TMTs of } 40 \text { Japanese firms from } 4 \text { industries listed } \\
\text { on the Tokyo Stock exchange }\end{array}$ & $\begin{array}{l}\text { Team tenure heterogeneity is positively related to team } \\
\text { turnover }\end{array}$ \\
\hline \multirow[t]{2}{*}{ b. organisation } & Wagner, Pfeffer and O'Reilly (1984) & $\begin{array}{l}599 \text { top management group members in } 31 \text { Fortune } \\
500 \text { companies }\end{array}$ & $\begin{array}{l}\text { Organisational tenure heterogeneity is positively related to } \\
\text { team turnover. Distant individuals are more likely to turn } \\
\text { over. }\end{array}$ \\
\hline & Bantel and Jackson (1989) & $\begin{array}{l}\text { TMTs of } 199 \text { banking companies in } 6 \text { American } \\
\text { states }\end{array}$ & $\begin{array}{l}\text { No association between organisational tenure heterogeneity } \\
\text { and innovation }\end{array}$ \\
\hline
\end{tabular}

\begin{tabular}{|l|l|l|l||}
\hline \hline COMPOSITIONAL VARIABLES & Authors & Sample & Findings \\
\hline \hline
\end{tabular}




\begin{tabular}{|c|c|c|c|}
\hline 3. Educational background variety & $\begin{array}{l}\text { Hambrick and d'A veni (1992) } \\
\text { Michel and Hambrick (1992) } \\
\text { Wiersema and Bantel (1992) } \\
\text { Haleblian and Finkelstein (1993) } \\
\text { Wiersema and Bird (1993) } \\
\text { Smith et al. (1994) } \\
\text { Bantel and Jackson (1989) } \\
\text { Wiersema and Bantel (1992) }\end{array}$ & 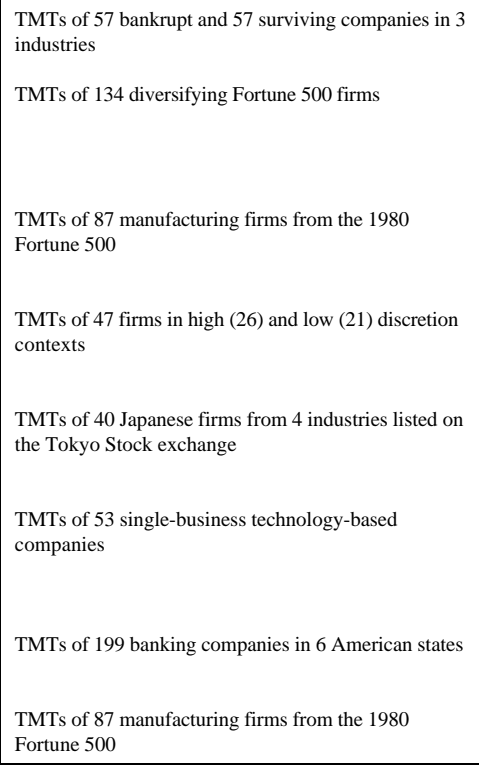 & 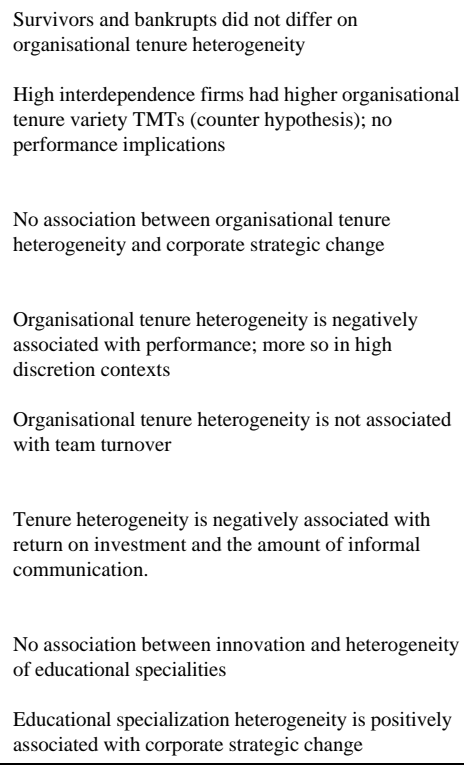 \\
\hline
\end{tabular}

\begin{tabular}{|l|l|l|l||}
\hline COMPOSITIONAL VARIABLES & Authors & Sample & Findings \\
\hline
\end{tabular}




\begin{tabular}{|c|c|c|c|}
\hline \multirow[t]{2}{*}{-continued- } & Wiersema and Bantel (1993) & $\begin{array}{l}\text { TMTs of } 85 \text { manufacturing firms in the } 1980 \text { Fortune } \\
500\end{array}$ & $\begin{array}{l}\text { Educational curriculum heterogeneity does not affect } \\
\text { turnover }\end{array}$ \\
\hline & Smith et al. (1994) & $\begin{array}{l}\text { TMTs of } 53 \text { single-business technology-based } \\
\text { companies }\end{array}$ & $\begin{array}{l}\text { Heterogeneity in the years of education has a direct } \\
\text { positive effect on both ROI and sales growth }\end{array}$ \\
\hline \multirow[t]{3}{*}{ 4. Functional variety } & Michel and Hambrick (1992) & TMTs of 134 diversifying Fortune 500 firms & $\begin{array}{l}\text { TMTs in high interdependence firms had more } \\
\text { heterogeneous functional backgrounds (counter } \\
\text { hypothesis) }\end{array}$ \\
\hline & Haleblian and Finkelstein (1993) & $\begin{array}{l}\text { TMTs of } 47 \text { firms in high (26) and low (21) discretion } \\
\text { contexts }\end{array}$ & $\begin{array}{l}\text { Marginal negative effect of functional heterogeneity on } \\
\text { performance in high discretion firms }\end{array}$ \\
\hline & Smith et al. (1994) & $\begin{array}{l}\text { TMTs of } 53 \text { single-business technology-based } \\
\text { companies }\end{array}$ & $\begin{array}{l}\text { Functional heterogeneity has direct nor indirect impact } \\
\text { on performance }\end{array}$ \\
\hline 5. 'Temporal and occupational variety' & Murray (1989) & $\begin{array}{l}\text { TMTs of } 84 \text { Fortune } 500 \text { food (58) and oil (26) } \\
\text { companies between } 1967 \text { and } 1981\end{array}$ & $\begin{array}{l}\text { Temporal heterogeneity enhances long-run performance, } \\
\text { but not shotrtrun performance. No effects in the low } \\
\text { TMT discretion (food) industry. No effects of } \\
\text { occupational variety }\end{array}$ \\
\hline
\end{tabular}

TABLE 1

Overview TMT studies on hypothesis level 


\begin{tabular}{|c|c|c|c|c|c|}
\hline Team characteristic & \# TMT studies & \# hypotheses & $\%$ confirmed & $\%$ no result & $\begin{array}{l}\% \text { counter } \\
\text { hypothesis }\end{array}$ \\
\hline \multicolumn{6}{|l|}{ Average... } \\
\hline Age & 2 & 2 & 50 & 50 & 0 \\
\hline Team tenure & 3 & 6 & 17 & 67 & 17 \\
\hline Organisational tenure & 5 & 8 & 75 & 25 & 0 \\
\hline Educational level & 2 & 2 & 100 & 0 & 0 \\
\hline Functional orientation & 2 & 3 & 67 & 0 & 33 \\
\hline \multicolumn{6}{|l|}{ Variety of ... } \\
\hline Age & 4 & 4 & 50 & 50 & 0 \\
\hline Team tenure & 3 & 3 & 33 & 67 & 0 \\
\hline Organisational tenure & 8 & 13 & 31 & 62 & 8 \\
\hline Education & 4 & 8 & 37 & 63 & 0 \\
\hline Function ${ }^{*}$ & 2 & 5 & 0 & 80 & 20 \\
\hline Total & 12 & 54 & 41 & 52 & 7 \\
\hline
\end{tabular}

Study by Haleblian and Finkelstein (1993) left out as the characteristic is entered only as a control variable for which no hypothesized effect is stated 
Figure 1: Original model (Hambrick and Mason, 1984)

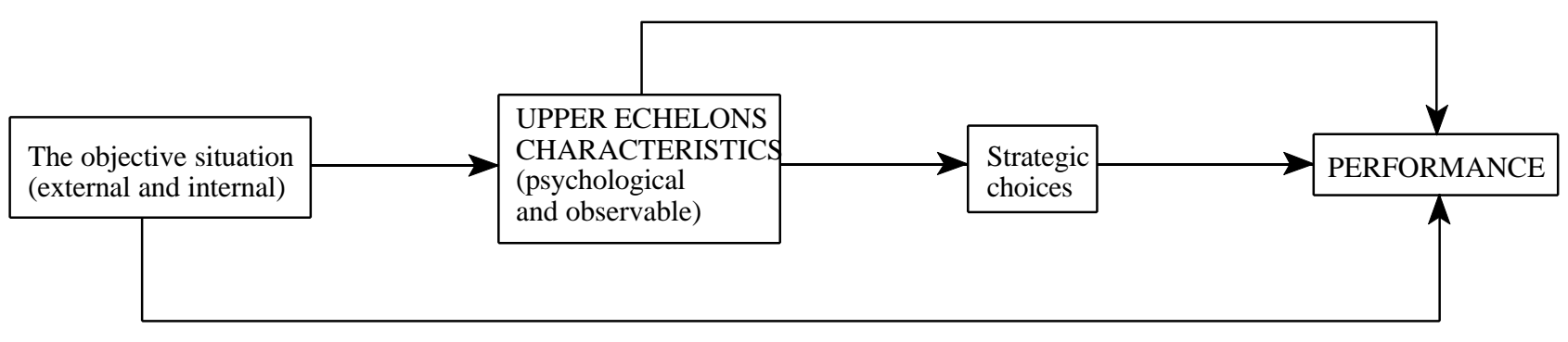


Figure 2: Stylized model of TMT composition effects

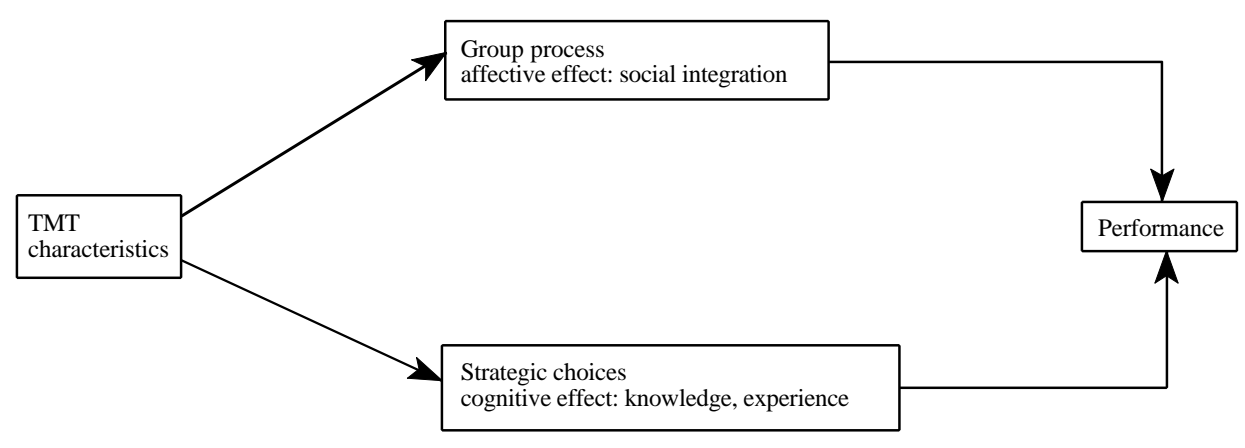

